DOI: https://doi.org/10.31933/jemsi.v2i6 Received: 5 April 2021, Revised: 25 Juni 2021, Publish: 11 Juli 2021

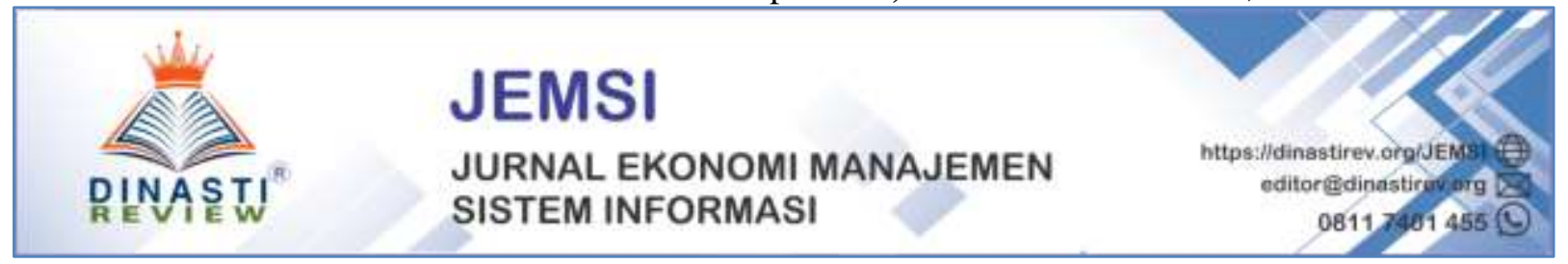

\title{
FUNGSI PERLINDUNGAN KONSUMEN DAN PERAN LEMBAGA PERLINDUNGAN KONSUMEN DI INDONESIA : PERLINDUNGAN, KONSUMEN DAN PELAKU USAHA(LITERATURE REVIEW)
}

\author{
Alfina Maharani ${ }^{1}$, Adnand Darya Dzikra ${ }^{2}$ \\ ${ }^{1}$ Fakultas Ekonomi dan Bisnis UMB, alfina.maharani224@gmail.com \\ ${ }^{2}$ Fakultas Ekonomi dan Bisnis UMB, adnanddarya24@gmail.com
}

Korespondensi Penulis: Alfina Maharani ${ }^{1}$

\begin{abstract}
Abstrak: Penulisan ini dimaksudkan untuk mengetahui tentang perlindungan konsumen dan azas-azas yang berlaku di dalam Undang-Undang Perlindungan Konsumen sesuai Pasal 2 UU No 8 Tahun 1999. Konsumen adalah setiap orang pemakai barang, dan atau jasa yang tersedia dalam masyarakat baik bagi kepentingan diri sendiri, keluarga, orang lain, maupun makluk hidup lain dan tidak untu diperdagangkan. Perlindungan konsumen adalah segala upaya yang menjamin segala kepastian hukum untuk memberi perlindungan kepada Konsumen.Disamping itu membahas tentang hak dan kewajiban konsumen dan pelaku usaha. Sebagaimana rumusan Pasal 4 jo 5 Undang-undang Perlindungan Konsumen. Penegakan hukum Perlindungan Konsumen harus melibatkan banyak pihak terutama pemerintah dan Lembaga Perlindungan Konsumen dan lembaga pengawas lain, serta harus terkoordinasi dengan instansi-instansi terkait supaya terjadi keharmonisan dan tidak tumpangtindih kebijakan atau keputusan. Hal ini diharapkan dapat mendorong pertumbuhan ekonomi dengan baik tanpa harus merugikan konsumen atau pengguna barang/atau jasa. Karena keberadaan Undang-Undang Perlindungan Konsumen ini sudah cukup representatif untuk melindungi konsumen asalkan Undang-undang telah dipahami oleh pelaku usaha dan konsumen.
\end{abstract}

Keyword: Perlindungan Konsumen (Y), Perlindungan (X1), Konsumen(X2), Pelaku Usaha(X3)

\section{PENDAHULUAN}

\section{Latar Belakang Masalah}

Konsumen adalah setiap orang pemakai barang, dan atau jasa yang tersedia dalam masyarakat baik bagi kepentingan diri sendiri, keluarga, orang lain, maupun makhluk hidup lain dan tidak untuk diperdagangkan. Perlindungan konsumen adalah segala upaya yang menjamin segala kepastian hukum untuk memberi perlindungan kepada Konsumen. Tetapi apakah sesuai kenyataan saat ini konsumen benar-benar dapat terlindungi dan lebih mengecewakan yang terjadi konsumen sering dianak-tirikan oleh para produsen. Beberapa contoh kasus tentang makanan kemasan kadaluarsa berbentuk parcel, dan kini banyak beredar serta produk-produk lain yang kadaluarsa, tentu sangat berbahaya apabila dikonsumsi sebab jamur dan bakteri yang berada dalam makanan tersebut bisa menyebabkankeracunan.

Pengolahan daging sisa atau bekas dari hotel dan restoran yang diolah kembali, berita ini menggemparkan publik yang dikenal dengan sebutan daging limbah atau daging sampah. Sebutan namanya saja kita akan merasa jijik dan seakan-akan tidak percaya pada hal tersebut, namun ini benar-benar terjadi dan faktanya pelaku ditangkap dikawasan cengkareng, Jakarta Barat. Pengakuan pelaku benar-benar melakukan dan menjelaskan pula tahapan-tahapan yang dilakukannya dalam mengolah daging sampah tersebut. Antara lain; Limbah daging dibersihkan lalu dicuci dengan cairan formalin, selanjutnya diberi pewarna tekstil dan daging digoreng 
kembali sebelum dijual dalam berbagai bentuk seperti sup, daging empal dan bakso sapi. Lebih mengejutkan lagi bahwa profesi ini sudah ia pratikkan selama 5(lima) tahun lebih.

Pernah kita mendengar tentang produk susu dari China yang mengandung melamin dan ditemukan di Indonesia. Melamin adalah zat yang biasa digunakan dalam pembuatan perabotan rumah tangga atau plastic. Namun dalam kasus ini melamin dicampurkan dicampurkan dengan susu dampak yang ditimbulkan adalah bayi yang mengalami penyakit tidak lazim seperti, gagal ginjal, bahkan tidak sedikit dari mereka yang meninggal dunia. Pelanggaranpelanggaran hukum yang dilakukan produsen dan atau pelaku usaha ini yang merugikan para konsumen dalam tingkatan yang dianggap sangat membahayakan kesehatandan jiwa konsumen.

Ketiga contoh kasus di atas, dapat memberikan gambaran bahwa konsumenlah menjadi pihakyang sangat dirugikan. Disamping itu sering kali konsumen harus membayar mahal untuk biaya berobat kerumah sakit karena resiko-resiko yang diderita adalah sangat membahayakan kesehatan dan jiwa konsumen. Terjadinya dampak seperti ini mungkin disebabkan kurangnya pengawasan dari Pemerintah dan badan-badan hukum seperti Dinas kesehatan, satuan Polisi Pamong Praja, serta dinas Perdagangan dan setempat.

\section{Rumusan Masalah}

Berdasarkan latar belakang akan di rumuskan masalah yang akan di bahas pada artikel literature review agar lebih fokus pada kajian pustaka dan hasil serta pembahasan nanti, yaitu:

1. Apakah azas-azas perlindungan konsumen ?

2. Apakah Hak dan kewajiban konsumen?

3. Bagaimanakah peran lembaga pengawasan dalam perlindungan konsumen?

\section{KAJIAN PUSTAKA}

Sesungguhnya peran hukum dalam konteks ekonomi adalah menciptakan ekonomi dan pasar yang kompetitif. Perlindungan konsumen harus mendapat perhatian yang lebih, karena investasi asing telah menjadi bagian pembangunan ekonomi Indonesia, dimana ekonomi Indonesia juga berkaitan dengan ekonomi dunia. Persaingan internasional dapat membawa implikasi negative bagi konsumen. Undang-Undang Perlindungan Konsumen menyatakan bahwa, perlindungan konsumen adalah segala upaya yang menjamin adanya kepastian hukum untuk memberi perlindungan kepada konsumen. Cakupan perlindungan konsumen itu dapat dibedakan dalam dua aspek, yaitu :

1. Perlindungan terhadap kemungkinan barang yang diserahkan kepada konsumen tidak sesuai dengan apa yang telah disepakati.

2. Perlindungan terhadap diberlakukannya syarat-syarat yang tidak adil kepada konsumen.

Az. Nasution berpendapat bahwa hukum perlindungan konsumen adalah bagian dari hukum konsumen yang memuat asas-asas atau kaidah-kaidah yang bersifat mengatur dan mengandung sifat yang melindungi kepentingan konsumen, sedangkan hukum konsumen adalah hukum yang mengatur hubungan dan masalah antara berbagai pihak satu sama lain berkaitan dengan barang atau jasa konsumen di dalam pergaulan hidup. Namun ada pula yang berpendapat bahwa hukum perlindungan konsumen merupakan bagian dari hukum konsumen. Hal ini dapat kita lihat bahwa hukum konsumen memiliki skala yang lebih luas karena hukum konsumen meliputi berbagai aspek hukum yang didalamnya terdapat kepentingan pihak konsumen dan salah satu bagian dari hukum konsumen ini adalah aspekperlindungannya, misalnya bagaimana cara mempertahankan hakhak konsumen terhadap gangguan pihak lain. 
Hukum perlindungan konsumen yang berlaku di Indonesia memiliki dasar hukum yang telah ditetapkan oleh pemerintah. Dengan adanya dasar hukum yang pasti, perlindungan terhadap hak-hak konsumen bisa dilakukan dengan penuh optimisme. Pengaturan tentang hukum perlindungan konsumen telah diatur dalam Undang-Undang No. 8 Tahun 1999 tentang Perlindungan Konsumen. Berdasarkan Pasal 1 angka 1 UUPK disebutkan bahwa Perlindungan konsumen adalah segala upaya yang menjamin adanya kepastian hukum untuk memberi perlindungan kepada konsumen. Kepastian hukum untuk memberi perlindungan kepada konsumen berupa perlindungan terhadap hak-hak konsumen, yang diperkuat melalui undangundang khusus, memberi harapan agar pelaku usaha tidak bertindak sewenang- wenang yang selalu merugikan hak-hak konsumen.

Keinginan yang hendak dicapai dalam perlindungan konsumen adalah menciptakan rasa aman bagi konsumen dalam memenuhi kebutuhan hidup. Segala upaya yang dimaksudkan dalam perlindungan konsumen tersebut tidak saja terhadap tindakan preventif tetapi juga tindakan represif dalam semua bidang perlindungan yang diberikan kepada konsumen, maka pengaturan perlindungan konsumen dilakukan dengan :

1. Menciptakan system perlindungan konsumen yang mengandung unsur keterbukaanakses informasi, serta menjamin kepastian hukum.

2. Melindungi kepentingan konsumen pada khususnya dan kepentingan seluruh pelakuusaha.

3. Meningkatkan kualitas barang dan pelayanan jasa.

4. Memebrikan perlindungan kepada konsumen dari praktik usaha yang menipu dan menyesatkan.

5. Memadukan penyelenggaraan, pengembangan, dan pengaturan perlindungan konsumen dengan bidang-bidang perlindungan pada bidang-bidang lainnya.

\section{METODE PENELITIAN}

Metode penulisan artikel ilmiah ini adalah dengan metode kualitatif dan studi literature atau Library Research. Mengkaji Buku-buku literature sesuai dengan teori yang di bahas khusunya di lingkup Manajemen Sumberdaya Manusia (MSDM) / Manajemen Pemasaran. Disamping itu menganalisis artikel-artikel ilmiah yang bereputasi dan juga artikel ilmiah dari jurnal yang belum bereputasi. Semua artikel ilmiah yang di citasi bersumber dari Mendeley dan Scholar Google.

Dalam penelitian kualitatif, kajian pustaka harus digunakan secara konsisten dengan asumsi-asumsi metodologis. Artinya harus digunakan secara induktif sehingga tidak mengarahkan pertanyaan-pertanyaan yang diajukan oleh peneliti. Salah satu alasan utama untuk melakukan penelitian kualitatif yaitu bahwa penelitian tersebut bersifat eksploratif, (Ali \& Limakrisna, 2013).

Selanjutnya dibahas secara mendalam pada bagian yang berjudul" Pustaka Terkait" (Related Literature) atau Kajian pustaka( "Review of Literature"), sebagai dasar perumusan hipotesis dan selanjutnya akan menjadi dasar untuk melakukan perbandingan dengan hasil atau temuan-temuan yang terungkap dalam penelitian, (Ali \& Limakrisna, 2013).

\section{HASIL DAN PEMBAHASAN \\ Azas Perlindungan Konsumen}

Undang-Undang Dasar 1945, merupakan sumber dari segala sumber hukum di Indonesia, dan dalam hal ini telah mengamanatkan pembangunan nasional bertujuan untuk mewujudkan masyarakat adil dan makmur. Melalui tujuan pembangunan nasional ini maka sistem pembangunan ekonomi harus dikembangkan secara demokratis sserta mampu menumbuhkan kembangkan dunia produksi barang dan jasa yang layak dikonsumsi oleh masyarakat. UndangUndang No. 8 Tahun 1999 tentang PerlindunganKonsumen (UUPK), diharapkan dapat 
memberikan rasa aman dan adil bagi masyarakat atau konsumen serta untuk memperoleh perlindungan atas kerugian yang diderita atas transaksi suatu barang dan jasa. Perkembangan perekonomian dan pertumbuhan pembangunan serta pengaruh globalisasi dan kemajuan teknologi akan membawa pengaruh luar biasa kepada setiap aspek kehidupan manusia, khususnya di bidang perindustian dan perdagangan yang menghasilkan barang jasa dalam pemenuhan kebutuhan hidup. Keadaan inilah sangat membawa keuntungan bagi pelaku usaha terhadap barang-barang yang dihasilkannya dan konsumen akan semakin terbukasebagai peluang untuk mengkomsumsi barang atau jasa yang dihasilkan dengan harga yang kompetitif. Keuntungan antara pelaku usaha dengan konsumen tersebut ada baiknya tetapi juga akan menimbulkan dampak negatik karena akan mengakibatkan kedudukan pelaku usaha dan konsumen menjadi tidak seimbang, pelaku usaha berposisi sebagai pensuplai dan konsumen berada pada posisi yang lemah. Dengan demikian Konsumen sebagai objek bisnis untuk meraup keuntungan yang sebesar-besarnya, pelaku usaha melalui kiat-kiat promosi dan tata cara penjualan yang merugikan konsumen. Maka UndangUndang Perlindungan Konsumen ini lahir sudah cukup representatif apabila telah dipahami oleh semua pihak, karena di dalamnya juga memuat jaminan adanya kepastian hukum bagi konsumen, meningkatkan kualitas barang dan/atau jasa yang menjamin kelangsungan usaha produksi barang dan/atau jasa, kesehatan, kenyamanan, keamanan dan keselamatan konsumen, meningkatkan kesadaran, kemampuan dan kemandirian konsumen untuk melindungi diri, mengangkat harkat dan martabat konsumen dengan cara menghindarkannya dari ekses negatifpemakaian barang dan/atau jasa, meningkatkan pemberdayaan konsumen dalam memilih,menentukan dan menuntut hak-haknya sebagai konsumen. Kemudian di dalam rumusannya pun telah mengatur pula tentang pelarangan bagi pelaku usaha yang tidak mengikuti ketentuan berproduksi secara halal, sebagaimana pernyataan "halal" yang dicantumkan dalam label. Seiring semakin terbukanya pasar bebas sebagai akibat dari proses mekanisme pasar yang berkembang. Ekses yang seringkali timbul adalah transaksi ekonomi yang terjadi sering terdapat permasalahan-permasalahan atau sengketa dan ketidakpuasan konsumen atas produk yang di konsumsinya tidak memenuhi kualitas rasa aman dan bahkan ada yang berbahaya.

Pemerintah melalui lembagalembaganya meningkatkan perlindungan dan jaminan produk, kepastian mutu, jumlah, dan keamanan barang dan jasa yang diperolehnya di pasar, hal ini demi peningkatan kesejahteraan masyarakat. Tentu masih segar di ingatan, ditariknya produk pengusir nyamuk HIT karena dikhawatirkan mengandung bahan yang berbahaya bagi keamanan dan keselamatan konsumen.

Terakhir tetang kasus jamu berbahaya, kosmetik, makananminuman mengandung susu produk RRC yang berbahaya, makanan yang bercampur formalin. beras mengandung bahan pengawet berbahaya dan lain-lain. Pertanyaannya kenapa lembagalembaga pemerintah seakanakan tidak berfungsi? Padahal secara nyata Pasal 2 UU No 8 Tahun 1999 merumuskan bahwa azas Perlindungan Konsumen adalah:

1. Asas Manfaat; mengamanatkan bahwa segala upaya dalam penyelenggaraan perlindungan konsumen harus memberikan manfaat sebesar-besarnya bagi kepentingan konsumen dan pelaku usaha secara keseluruhan,

2. Asas Keadilan; partisipasi seluruh rakyat dapat diwujudkan secara maksimal dan memberikan kesempatan kepada konsumen dan pelaku usaha untuk memperoleh haknya dan melaksanakan kewajibannya secara adil

3. Asas Keseimbangan; memberikan keseimbangan antara kepentingan konsumen, pelakuusaha, dan pemerintah dalam arti materiil ataupun spiritual,

4. Asas Keamanan dan Keselamatan Konsumen; memberikan jaminan atas keamanan dankeselamatan kepada konsumen dalarn penggunaan, pemakaian dan pemanfaatan barangdan/atau jasa yang dikonsumsi atau digunakan;

5. Asas Kepastian Hukum; baik pelaku usaha maupun konsumen mentaati hukum dan 
memperoleh keadilan dalam penyelenggaraan perlindungan konsumen, serta Negara menjamin kepastian hukum.

Kesadaran konsumen akan hakhaknya masih rendah, hal ini dipengaruhi beberapa faktor, seperti tingkat pendidikan yang belum memenuhi standar wajib karenanya belum dapat dianggap sebagai konsumen yang cerdas. Undang-Undang Perlindungan Konsumen dimaksudkan untuk menjadi landasan hukum yang kuat bagi pemerintah dan lembaga perlindungan konsumen swadaya masyarakat untuk melakukan upaya pemberdayaan konsumen melalui pendidikan dan pembinaan konsumen. Upaya pemberdayaan ini penting karena tidak gampang menyadarkan pelaku usaha yang telah mendarah daging berpegang teguh dengan prinsipnya," mengeluarkan barang atau modal minimal tetapi mendapatkan keuntungan yang semaksimal mungkin. Konsisi ini sangat potensial merugikan kepentingan konsumen secara langsung maupun tidaklangsung

\section{Hak Dan Kewajiban Konsumen}

Rumusan pasal-pasal UU Nomor 8 Tahun 1999, telah mengatur Hak-hak konsumen dan pelaku usaha, Meskipun realitanya, terkadang konsumen seringkali berada pada posisi yang kurang menguntungkan dan daya tawarnya rendah. Ini karena mereka belum memahami hak-hak mereka dan terkadang sudah menganggap itu persoalan biasa saja. Untuk Lembaga pelindungan Konsumen swadaya masyarakat adalah lembaga advokasi kepentingan konsumen yang secara idial mampu memperjuangkan hak-hak konsumen, adapun sesuai dengan Pasal 4 Undangundang Perlindungan Konsumen, Hak-hak Konsumen adalah :

a) Hak atas kenyamanan, keamanan dan keselamatan dalam mengkonsumsi barangdan/atau jasa;

b) Hak untuk memilih barang dan/atau jasa serta mendapatkan barang dan/atau jasatersebut sesuai dengan nilai tukar dan kondisi serta jaminan yang dijanjikan;

c) Hak atas informasi yang benar, jelas dan jujur mengenai kondisi dan jaminan barang dan/atau jasa;

d) Hak untuk didengar pendapat dan keluhannya atas barang dan/atau jasa yangdigunakan;

e) Hak untuk mendapatkan advokasi, perlindungan dan upaya penyelesaian sengketa perlindungan konsumen secara patut;

f) Hak untuk mendapat pembinaan dan pendidikan konsumen;

g) Hak untuk diperlakukan atau dilayani secara benar dan jujur serta tidak diskriminatif;

h) Hak untuk mendapatkan kompensasi, ganti rugi/penggantian, apabila barang dan/atau jasa yang diterima tidak sesuai dengan perjanjian atau tidak sebagaimana mestinya;

i) Hak-hak yang diatur dalam ketentuan peraturan perundangundangan lainnya.

Maka dengan demikian konsumen pun perlu memiliki dan meningkatkan kesadaran, pengetahuan, kepedulian, kemampuan untuk melindungi dirinya. Sosialisasi Undangundang perlindungan konsumen harus secara gencar dilakukan terutama kepadamasyarakat tingkat bawa dan berpendidikan rendah. Karena permasalahan- permasalahan ini tentu akan terjadi akibat dari ketidak pahaman konsumen. Untuk peningkatan kesadaran dan kewaspadaan konsumen, sesuai rumusan Pasal 5 Undang-undang perlindungan konsumen, memiliki kewajiban sebagai berikut:

1. Membaca atau mengikuti petunjuk informasi dan prosedur pemakaian atau pemanfaatan barang dan/atau jasa, demi keamanan dan keselamatan;

2. Beritikad baik dalam melakukan transaksi pembelian barang dan/atau jasa;

3. Membayar sesuai dengan nilai tukar yang disepakati;

4. Mengikuti upaya penyelesaian hukum sengketa perlindungan konsumen secarapatut.

Seperangkat penegakan hukum ada untuk melindungi konsumen dan tidak dimaksudkan untuk mematikan usaha para pelaku usaha, namun timbal balik ini perlindungan konsumen dapat mendorong iklim perusahaan yang tangguh dalam menghadapi persaingan melalui penyediaan barang dan atau jasa yang berkualitas. Pelaksanaan Undangundang Perlindungan konsumen tetap 
memberikan perhatian khusus kepada pelaku usaha kecil dan menengah. Hal ini dilakukan melalui upaya pembinaan dan penerapan sanksi atas pelanggarannya Disamping itu sesuai Pasal 6 Undang-undang Perlindungan konsumen, merumuskan hak pelaku usaha adalah:

a. hak untuk menerima pembayaran yang sesuai dengan kesepakatan mengenaikondisi dan nilai tukar barang dan/atau jasa yang diperdagangkan;

b. hak untuk mendapat perlindungan hukum dari tindakan konsumen yang beritikadtidak baik;

c. hak untuk melakukan pembelaan diri sepatutnya di dalam penyelesaian hukum sengketa konsumen;

d. hak untuk rehabilitasi nama baik apabila terbukti secara hukum bahwa kerugian konsumen tidak diakibatkan oleh barang dan/atau jasa yang diperdagangkan;

e. hak-hak yang diatur dalam ketentuan peraturan perundang-undangan lainnya,Adapun sesuai Pasal 7, merumuskan kewajiban pelaku usaha adalah :

1) beritikad baik dalam melakukan kegiatan usahanya;

2) memberikan informasi yang benar, jelas dan jujur mengenai kondisi dan jaminan barangdan/atau jasa serta memberi penjelasan penggunaan, perbaikan dan pemeliharaan;

3) memperlakukan atau melayani konsumen secara benar dan jujur serta tidak diskriminatif;

4) menjamin mutu barang dan/atau jasa yang diproduksi dan/atau diperdagangkan berdasarkanketentuan standar mutu barang dan/atau jasa yang berlaku;

5) memberi kesempatan kepada konsumen untuk menguji, dan/atau mencoba barang dan/atau jasa tertentu serta memberi jaminan dan/atau garansi atas barang yang dibuat dan/atau yangdiperdagangkan;

6) memberi kompensasi, ganti rugi dan/atau penggantian atas kerugian akibat penggunaan, pemakaian dan pemanfaatan barang dan/atau jasa yang diperdagangkan;

7) memberikompensasi, ganti rugi dan/atau penggantian apabila barang dan/atau jasa yang diterima atau dimanfaatkan tidak sesuai dengan perjanjian.

\section{Peran Lembaga Pengawasan Dalam Perlindungan Konsumen}

Peran lembaga Perlindungan Konsumen swadaya masyarakat, yang bergerak di bidang perlindungan konsumen menjadi sangat dibutuhkan dalam masyarakat, perannya yang diakui oleh pemerintah memiliki kesempatan untuk berperan aktif dalam mewujudkan perlindungan konsumen. Lembaga perlindungan konsumen swadaya Masyarakat ini berdiri atas perintah undang-undang dan diakui keberadaannya dan memiliki kegiatan sebagaimana rumusan Pasal 44 Undang-undang Perlindungan Konsumen, antara lain:

a. menyebarkan informasi dalam rangka meningkatkan kesadaran atas hak dankewajiban dan kehatihatian konsumen dalam mengkomsumsi barang dan/atau jasa;

b. memberikan nasehat kepada konsumen yang memerlukannya;

c. bekerja sama dengan instansi terkait dalam upaya mewujudkan perlindungankonsumen;

d. membantu konsumen dalam memperjuangkan haknya, termasuk menerima keluhanatau pengaduan konsumen;

e. melakukan pengawasan bersama pemerintah dan masyarakat terhadap pelaksanaan perlindungan konsumen.

Disisi lain Lembaga Pengawasan dan/atau instansi pemerintah dapat dianggap bertanggungjawab terhadap pengawasan peredaran barang-barang dan jasa yang dikonsumsi masyarakat seperti, BPOM, DINKES dan departemen terkait yang mengeluarkan izin produksi, perdagangan dan peredaran suatu produk. Tidak mudah dikibuli oleh pelaku usaha yang akhirnya merugikan konsumen. Kasuskasus formalin,HIT, susu bercampur melamin sebenarnya yang diketahui oleh badan-badan pemerintah terkait tetapi sengaja di biarkan. Akan tetapi ketika kasus 
ini menjadi konsumsi publik dan

/atau heboh di media cetak maupun elektronik, barulah Pemerintah penindaklajuti, padahal sudak memakan korban yang tidak sedikit dan merugikan konsumen yang tidak dapat dihitung besarnya

\section{CONCEPTUAL FRAMEWORK}

Berdasarkan rumusan masalah penulisan artikel ini dan kajian studi literature review baik dari buku dan artikel yang relevan, maka di perolah rerangka artikel ini seperti di bawah ini.

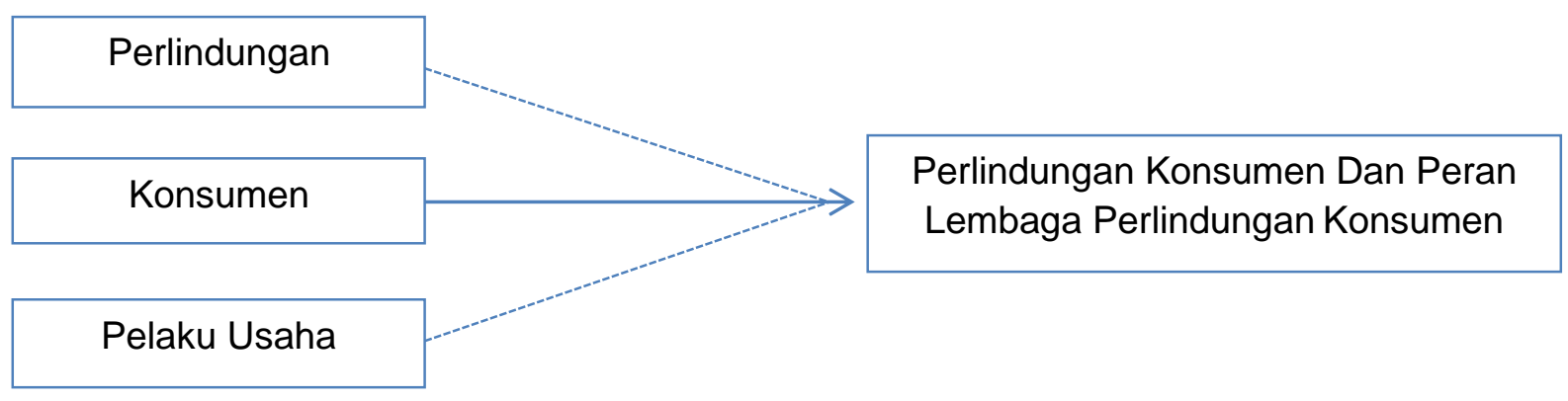

Gambar 1: Conceptual Framework

\section{KESIMPULAN DAN SARAN}

\section{Kesimpulan}

Keberadaan UU Perlindungan Konsumen ini sudah cukup representatif untuk melindungi konsumen asalkan Undang-undang telah dipahami oleh pelaku usaha dan konsumen. Peran lembaga perlindungan konsumen dan seperangkat penegak hukum lainnya harus secara bersamasama mendorong tumbuh kembangnya ekonomi tetapi juga tidak merugikan konsumen yang telah mengkonsumsi barang dan/atau jasa tersebut.

\section{Saran}

1) Untuk pemerintah dan lembaga perlindungan konsumen harus menegakkan UndangUndang secara baik sehingga mampu menjunjung tinggi Azas-azas yang berlaku dalam Undang-undang Perlindungan Konsumen.

2) Memenuhan hak dan Kewajiban konsumen dan Pelaku usaha sebagai asas keseimbangan sebagai salah satu pelaku usaha sehingga tercidan perlindungan hukum.

3) Meningkatkan peran serta Lembaga Perlindungan Konsumen swadaya masyarakatsebagai amanah Undangundang Perlindungan Konsumen.

\section{DAFTAR RUJUKAN}

Bandung Sudaryatmo. 1999. Hukum dan Advokasi Konsumen. PT. Citra Aditya Bakti.

Yusuf Sofie. 2000. Perlindungan Konsumen dan Instrumen-Instrumen Hukumnya. PT. CitraAditya Bakti,

Undang-Undang Nomor 8 Tahun 1999 Tentang Perlindungan Konsumen Bandung'http://www.scribd.com/doc/18545014/makalahperlindungankonsumenhttp://w ww.pemantaupe radilan.com/delik/16.

Erman Rajagukguk, 2000, Pentingnya Hukum Perlindungan Konsumen dalam Era Perdagangan Bebas, Mandar Maju, Bandung, h.2

Adrianus Meliala, 2006, Praktik Bisnis Curang, Pustaka Sinar Harapan, Jakarta, h.152

Az. Nasution, 2001, Hukum Perlindungan Konsumen Suatu Pengantar, Diadit Media, Jakarta,h.11 Happy Susanto, 2008, Hak-Hak Konsumen Jika Dirugikan, Visimedia, Jakarta, h.4

Abdul Halim Barkatulah, 2008, Hukum Perlindungan Konsumen (Kajian Teoretis dan 
Perkembangan Pemikiran, Nusa Media, Bandung,h.7 